\title{
PELATIHAN PERAWATAN DAN PERBAIKAN AC MOBIL BAGI SISWA SMK SIAP LULUS
}

\section{TRAINING REPAIR AND MAINTENANCE CAR AIR CONDITIONING FOR VOCATIONAL SCHOOL STUDENTS READY TO GRADUATE}

\author{
Marwan Effendy ${ }^{1)^{*}}$, Eqwar Saputra ${ }^{2)}$, Arif Surono ${ }^{3)}$ \\ ${ }^{1)}$ Teknik Mesin, Fakultas Teknik, Universitas Muhammadiyah Surakarta \\ email: marwan.effendy@ums.ac.id \\ ${ }^{2)}$ Teknik Mesin, Fakultas Teknik dan Sains, Universitas Muhammadiyah Purwokerto \\ email: eqwarsaputra@ump.ac.id \\ ${ }^{3)}$ Teknik Mesin, Politeknik Indonusa, Surakarta \\ email: arifsurono01@gmail.com
}

\begin{abstract}
ABSTRAK
Tulisan ini melaporkan kegiatan pengabdian pada masyarakat yang dilaksanakan di Sekolah Menengah Kejuruan (SMK) Harapan Kartasura. Pengabdian ini difokuskan pada siswa kelas 3 (tiga) yang siap lulus. Pengabdian ini bertujuan untuk memberikan pengetahuan dan keterampilan pada siswa mengenai perbaikan dan perawatan mesin Air Conditioning (AC) mobil. Melalui program ini diharapkan siswa lebih siap dalam mempersiapkan diri untuk memasuki dunia kerja. Pengabdian ini diawali dengan penyampaian teori, berupa materi materi komponen dasar dan sistem kerja mesin AC mobil. Materi disampaikan dengan metode ceramah, diskusi dan tanya jawab. Siswa diberikan pemahaman terkait cara pencucian unit AC (pembersihan indoor dan outdoor), pengecekan kerja mesin dan trouble shooting dalam AC. Pelatihan diikuti oleh 21 orang peserta. Hasil dari pelatihan ini, mampu memberikan keterampilan dan pemahaman berkaitan dengan $\mathrm{AC}$, sehingga dimungkinkan siswa dapat membuka usaha sendiri khususnya dalam bidang perawatan dan perbaikan AC yang baik dan benar.
\end{abstract}

Kata Kunci: AC, Pelatihan, Perbaikan, Perawatan, Siswa

\section{ABSTRACT}

This paper reports the activities of devotion to the community conducted in vocational High School (SMK) Harapan Kartasura. This devotion is focused on students in grade 3 (three) who are ready to graduate. This devotion aims to provide students with knowledge and skills regarding the repair and maintenance of car air conditioning machines. Through this program, students are expected to be better prepared to enter the workforce. This devotion begins with the submission of theories, the basic component materials and the working system of the car AC engine. The material is delivered by lecture, discussion and question, and answer methods. Students are given an understanding of how the air conditioning unit is washing (indoor and outdoor cleaning), performance checking and troubleshooting in the AC machine. The training was attended by 21 attendance. After this counseling, students are expected to have capable skills, so that they can open their own business, especially in the field of maintenance and repair of good and correct air conditioning.

Keywords: AC, Taining, Repairs, Maintenance, Student

\section{PENDAHULUAN}

Salah satu program yang dicanangkan
Sekolah Menengah Kejuruan (SMK) BISA.

oleh pemerintah melalui kementerian zaman menjadi tantangan yang harus pendidikan dan kebudayaan adalah program dihadapi oleh para pencari kerja [1]. 
Diharapkan melalui program SMK dapat AC pada mobil di Indonesia. Pada tahun menciptakan tenaga kerja yang mempunyai 2010 permintaan AC mencapai 1,3 juta keterampilan yang baik, sehingga mampu produk dan terus meningkat menjadi 1,6 juta bersaing dalam dunia kerja. Oleh karena itu produk pada tahun 2011. Hal ini sejalan pemerintah menambah jumlah SMK, baik dengan pertumbuhan rata-rata industri SMK negeri atau swasta. Namun, pendingin yang berkisar 25\%. Tingginya peningkatan jumlah SMK belum sepenuhnya pemakaian AC berpengaruh pada kesiapan mampu menghasilkan lulusan yang tenaga ahli untuk melakukan perbaikan dan berkualitas. Akhirnya, masih kita temui perawatan [5]. Apabila ada salah satu siswa SMK yang tidak bekerja setelah komponen yang rusak tentunya AC tidak mereka selesai mengenyam dunia bisa beroperasi dengan baik [6]. Usaha pendidikan. Berdasarkan data dari BPS [2] perbaikan AC sangat cocok dijalankan, mencatat bahwa tingkat pengangguran karena peluang kerja masih terbuka lebar, pendidikan SMK angkanya sangat tinggi mengingat tenaga ahli bidang ini masih dibandingkan dengan tingkat pengangguran tergolong langka. Sementara penggunaan jenjang pendidikan lainnya. Dilaporkan pada mesin pendingin (AC) sudah merambah bulan Februari 2016, tingkat pengangguran hingga berbagai lini kehidupan, bahkan pendidikan SMK sebesar 9,89\%,sementara hingga ke pelosok desa. Peluang ini dapat tingkat pengangguran berpendidikan SMA dimanfaatkan para siswa yang akan lulus sebanyak 6,95\% [3]. untuk membuka usaha jasa perbaikan dalam

Fakta empirik juga menunjukkan bahwa, bidang pendingin AC, seperti kulkas, sebagian besar lulusan SMK belum mampu dispenser dan pendingin lainnya yang secara memenuhi kebutuhan pasar. Selain itu, umum prinsip kerjanya sama. Kondisi lulusan SMK menjadi pencari kerja dan seperti inilah yang harus dimanfaatakan belum mampu untuk berwirausaha sebagai peluang usaha [7]. Program mengembangkan sekaligus pelatihan untuk SMK merupakan salah satu mengimplementasikan keahlian yang didapat solusi alternatif untuk meningkatkan di bangku sekolah SMK [4]. Oleh karena itu, kompetensi dalam pengetahuan dan untuk menciptakan lulusan SMK yang keterampilan yang dikuasai sehingga dapat mampu berwirausaha dan berdaya saing. meningkatkan, perilaku kognitif, afektif dan Kami melakukan pelatihan perawatan dan pkiskomotorik yang baik [8]. Selain itu, perbaikan AC mobil guna mewujudkan tersedia stand AC mobil yang dapat mandiri usaha. Hal ini didukung dengan digunakan sebagai media pembelajaran dan meningkatnya penggunaan pendingin udara percobaan untuk mengetahui kinerja [9]. 
Berdasarkan uraian diatas, maka kami Kerja kondensasi pada pada kondensor. melakukan pelatihan perbaikan dan Merupakan proses pelepasan kalor secara perawatan AC kapada para siswa SMK isobarik, menyebabkan penurunan panas Harapan Kartasura yangakan lulus. lanjut dan pengembunan refrigeran. Pada Diharapkan melalui penyuluhan ini dapat proses ini temperatur dan entalpi refrigeran meningkatkan kompetensi siswa SMK serta turun dan refrigeran mengalami perubahan menumbuhkan jiwa wirausaha, sehingga fase dari uap panas lanjut menjadi cair. nantinya mereka dapat membuat lapangan Selanjutnya, refrigeran mengalir melalui pekerjaan sendiri setelah selesai dibangku kondensor, dimana refrigerant mengembun sekolah.

\section{Prinsip Kerja AC Mobil} dan memberikan panas ke udara dan

Dalam melakukan pengabdian ini untuk mempermudah pemahaman siswa, maka memberikan panas ke udara sekitar yang secara umum kerja AC adalah, sebagai berikut :

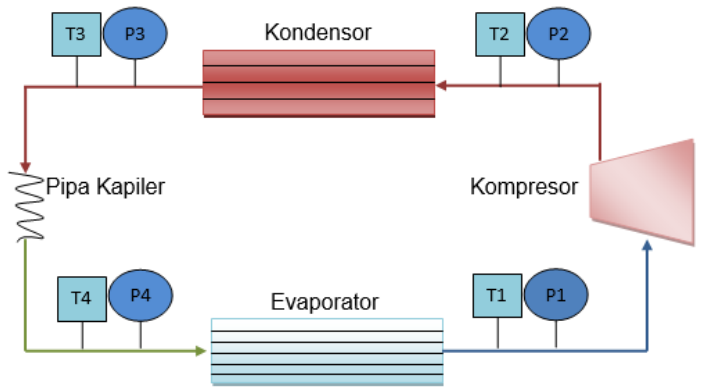

Gambar 1. Skematik Alat AC

lebih rendah temperaturnya.

Kerja ekspani pada katup ekspansi. Proses ekspansi dilakukan secara isentalpi, dari fase cair menuju tekanan evaporator. Proses ini tekanan dan temperatur refrigeran turun, mengalami perubahan fase dari cair menjadi uap jenuh. Proses pencekikan (throttling process) pada sistem pendingin terjadi di dalam pipa kapiler atau alat ekspansi.

Kerja evaporasi pada evaporator. Proses

Gambar 1 merupakan gambar skematik prinsip kerja dari AC mobil, berdasarkan urutan kerja.

\section{Prinsip Dasar kerja AC}

Kerja kompresi terjadi pada kompresor. Proses kompresi berlangsung secara refrigeran mengalir melalui evaporator, isentropik padakompesor. Pada proses ini perpindahan panas dari ruangan yang temperatur, tekanan dan entalpi refrigeran didinginkan menyebabkan refrigeran naik. Refrigeran mengalami perubahan fase menguap. dari uap kering menjadi uap panas lanjut. METODE PELAKSANAAN KEGIATAN Pada daerah ini refrigeran dikompresi hingga Metode yang digunakan untuk mencapai tekanan dan temperaturnya bertambah tinggi. target diatas, sebagai berikut : 


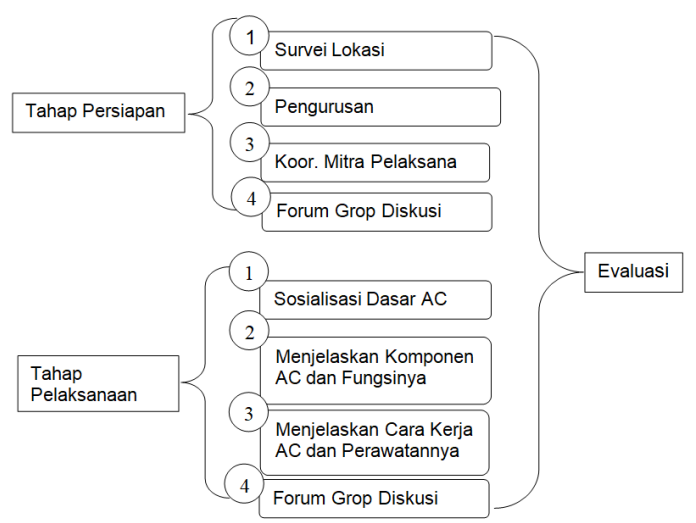

Gambar 2. Metode Pelaksanaan

Tahap Persiapan

Pada tahap pertama ini terdapat beberapa hal yang terkait dengan pelaksanaan penyuluhan yang dikoordinasikan oleh tim. Pada tahap awa melaklukan survei lokasi penyuluhan, untuk menganalisis kondisi peserta dan sekolahan. Kemudian, melakukan koordinasi dengan mitra untuk pelaksanaan penyuluhan. Hal ini dilakukan dengan pertimbangan bahwa penyuluhan yang akan dilaksanakan terkait dengan bidang ilmu mahasiswa yang dilibatkan. Metode yang dilakukan diantaranya adalah: Forum Group Diskusi (FGD) didalam ruang: Metode ini dilakukan dengan menyampaikan beberapa kajian teori, untuk menambah wawasan dan pengetahuan siswa sebelum melakukan praktik secara langsung.

\section{Tahap Pelaksanaan}

Pada tahap ini sosialisasi dasar AC, berfokus pada teori dan praktik yang berisi tentang cara, tim instruktur. Erzeddin, 2018 mengatakan bahwa dengan praktik langsung akan menguprgade dan meningkatkan kemampuan dan keterampilan peserta [10]. Pada tahap ini tim dari instruktur menyampaikan materi teori servis ringan mesin AC yang sesuai yg telah direncanakan oleh tim. Untuk mendukung penyuluhan maka dibekali dengan modul atau buku saku servis mesin AC. Hal ini dilakukan untuk mendukung proses pelatihan seperti : dasardasar AC, manfaat AC, sistem kerja AC, dan memberi motivasi tentang peluang mendirikan jasa perbaikan AC. Karena ada beberapa hal yang perlu diketahui mengenai AC itu sendiri.

\section{Tahap Akhir}

$$
\text { Melakukan evaluasi kegiatan, }
$$
pemberian motivasi berwirausaha. Tim Instruktur dan Tim Pengabdian. Evaluasi diperlukan untuk mengevaluasi kegiatan dari awal sampai akhir yang kemudian dilanjutkan dengan memberikan motivasi kepada para peserta. Hal ini dilakukan untuk meningkatkan semangat dari peserta untuk berwirausaha.

\section{HASIL DAN PEMBAHASAN}

Berdasarkan tercapainya kegiatan diatas maka diharapkan akan diperoleh beberapa target luaran dan target capaian, secara rinci adalah :

\section{Siswa mengetahui cara kerja AC}

Pada tahap pertama ini terdapat beberapa hal yang terkait dengan pelaksanaan penyuluhan dikoordinasikan oleh tim. Hal ini dilakukan dengan pertimbangan bahwa penyuluhan yang akan 
dilaksanakan terkait dengan bidang ilmu peserta akan mudah paham dan bisa untuk mahasiswa yang dilibatkan. Metode yang mempraktekkannya secara langsung. Pada dilakukan diantaranya adalah: Forum Group tahap ini tim dari instruktur menyampaikan Diskusi (FGD) didalam ruang: Metode ini materi teori servis ringan mesin AC yang dilakukan dengan menyampaikan beberapa sesuai yg telah direncanakan oleh tim. Untuk kajian teori, untuk menambah wawasan dan mendukung penyuluhan maka dibekali pengetahuan siswa sebelum melakukan dengan modul atau buku saku servis mesin praktik secara langsung. Hal ini dilakukan AC.

untuk mendukung proses pelatihan seperti : dasar-dasar AC, manfaat AC, sistem kerja $\mathrm{AC}$, dan memberi motivasi tentang peluang mendirikan jasa perbaikan AC. Karena ada beberapa hal yang perlu diketahui mengenai AC itu sendiri.
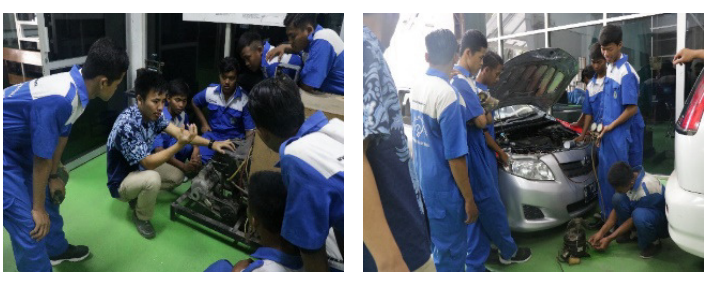

Gambar 4 Pemberian penjelasan secara langsung komponen AC dan Cara Kerjanya

\section{Siswa mengetahui cara perbaikan AC dan Peralatannya}

Peserta melakukan perbaikan secara langsung pada mobil, dengan cara menguji performa AC, menguji kebocoran AC, praktik pengisian refrigeran dan cara

Peserta sangat antusias dalam mendengarkan materi, berkaitan dengan perawatan dan perbaikan mesin AC. Materi diberikan didalam kelas selama 2 jam (1 jam penyampaian materi ; 1 jam tanya jawab). Setelah selesai, kemudian dilanjutkan dengan praktik secara langsung.

Siswa Mengetahui komponen-komponen dan fungsi $\mathrm{AC}$

Untuk memahamkan peserta, maka tim melakukan penjelasan secara langsung dilapangan. Siswa dikenalkan macammacam komponen dan cara kerja masingmasing komponen dengan diperlihatkan wujud fisik dari perlatan tersebut. Sehingga, pemvakuman. Metode paktek penting dilakukan untuk mengetahu tingkat pemahaman siswa dalam menerima teori. Praktik ini dilakukan diantaranya terkait cara mengisi refrigerant, pemvakuman. Setelah itu tahap akhir proses evaluasi kegiatan dan pemberian motivasi berwirausaha. Evaluasi diperlukan untuk mengevaluasi kegiatan dari awal sampai akhir yang kemudian dilanjutkan dengan memberikan motivasi kepada para peserta. Hal ini dilakukan untuk meningkatkan semangat dari peserta untuk berwirausaha. 

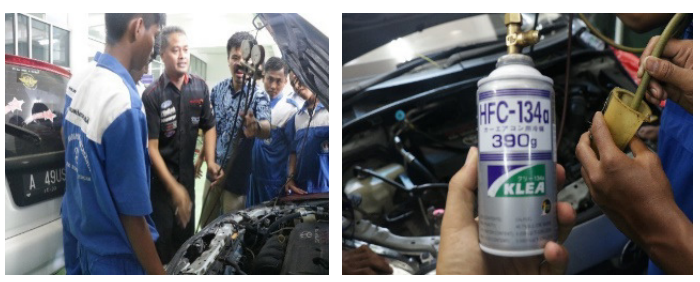

Gambar 5. Praktik perbaikan AC pada Mobil

Dengan penyuluhan ini, berbekal ilmu pengetahuan yang benar para lulusan SMK diharapkan mampu menentukan upaya preventif. Dengan mengetahui nilai peluang yang bisa diambil dari penyuluhan ini. Sehingga mampu mengurangi pengangguran dan menambah jumlah wirausaha di Indonesia yang bergerak dalam bidang AC.

\section{KESIMPULAN}

Peserta memiliki pengetahuan tentang peluang dan pentingnya usaha bidang $\mathrm{AC}$, terbukti antusias dan semangat peserta dalam mengikuti kegiatan pelatihan perbaikan dan perawatn AC mobil dari awal hingga akhir. Munculnya pertanyaan-pertanyaan dan forum group diskusi (FGD) didalam kelas maupun diluar kelas saat praktik, membuktikan rasa keingintahuan peserta yang sangat tinggi. Kegiatan ini dilakukan dengan jumlah peserta 21 orang. Pelatihan dilakukan melalui 2 (dua) sesi, teori dikelas dan praktik, sehingga siswa dapat memahami komponen-komponen $\mathrm{AC}$ dan sistem kerjanya. Sebagian besar peserta memiliki keterampilan perawatan dan cara memperbaiki AC, servis ringan seperti tes kebocoran, pengecekan tekanan refrigeran, pemvakuman dan pengisian refrigeran.

\section{UCAPAN TERIMAKASIH}

Penulis mengucapkan terimakasih kepada Universitas Muhammadiyah Surakarta yang telah memberikan dukungan pembiayaan pada pengabdian masyarakat ini. Selain itu, kepada pihak SMK Harapan Kartasura yang bersedia menjadi mitra dan membantu pelaksanaan pengabdian ini.

\section{REFERENSI}

[1] Hidayat,Dayat. 2017. Pelatihan Keterampilan Otomotif untuk meningkatkan Kesempatan Kerja di Balai Latihan Kerja Kabupaten Karawang, Journal of Nonformal Education and Community Empowerment Vol 1 (1): 55-63.

[2] Badan Pusat Statistik (BPS). 2016. Survei Keadaan Angkatan Kerja (Sakernas) 2016. Jakarta: BPS.

[3] Demografi Fakultas Ekonomi dan Bisnis Universitas Indonesia (LD FEB UI). 2014. Laporan Akhir. Analisis Lulusan SMK di Pasar Kerja Indonesia.

[4] Subijanto. 2012. Analisis Pendidikan Kewirausahaan di Sekolah Menengah Kejuaruan. Jurnal Pendidikan dan Kebudayaan. Vol.18, NO. 2.

[5] Kementerian Ketenagakerjaan Republik Indonesia. 2016. Penetapan Standar Kompetensi Nasional Kategori Industri Pengolahan Golongan Pokok Industri Mesin dan Perlengakapan lainnya Bidang Industri Air Conditioning (AC). SKKNI.

[6] Rahardjo, I. A. 2017. Penyuluhan Perbaikan dan Perawatan Air Conditioner (AC). Jurnal Sarwahita Vol 13 No.1.

[7] Jusnita, Hasan, Indra., Fauz, M, Ridha., Yuhelson., Japri. (2017). Program bengkel dan pelatihan training otomotif di Kelurahan labuhratu barat Kecamatan 
Payung Sekaki Pekanbaru, vol.1, No.2 ISSN: 2550-0198.

[8] Setiawan, Dedi., Saputra, H, Dani., Chaniago, Muslim. 2019. Pelatihan Keterampilan Membangun Bisnis(Wirausaha) Bengke Sepeda Motor Secara Mandiri Bagi Siswa SMK, vol.20, No.1, pp.21-28.

[9] Effendy,Marwan. 2005. Pengaruh Kecepatan Udara Pendingin Kondensor terhadap Koefisien Prestasi Air
Conditioning, Jurnal Teknik GELAGAR vol 16 No 1 April 2005., Fakultas Teknik Universitas Muhammadiyah Surakarta, pp 51-58.

[10] Erzeddin, Alwi., Hidayat., Nuzul, Wanda. 2018. Program Up-grade Skill service sepeda motor bagi mekanik bengkel pemula di Jorong koto Malintang. Pakar Pendidikan, 16 (1), 16-21. 